\title{
IbM KELOMPOK PETERNAK SAPI DESA HADIWARNO KAB. PACITAN DALAM PEMANFAATAN ENERGI ALTERNATIF
}

\author{
Eko Noerhayati ${ }^{1}$ Bambang Dwi Sulo ${ }^{2}$ \\ ${ }^{1}$ Jurusan Teknik Sipil Iniversitas Islam Malang \\ email: eko unisma@ymail.com \\ 2 Jurusan Teknik Elektro Universitas Islam Malang \\ email: bambangsd@unisma.ac.id
}

\begin{abstract}
ABSTRAK
Desa Hadiwarno adalah sebuah desa di Kab. Pacitan yang termasuk dalam kecamatan Ngadirojo. Warga desa ini memiliki kelompok tani yang bergerak dibidang budidaya sapi pedaging. Anggotanya 43 orang yang rata-rata masing-masing memiliki 2-3 ekor sapi yang diletakkan dalam satu kandang. Jadi total jumlah sapi yang diternakkan 86 ekor. Selama ini kotoran sapi dimanfaatkan sebagai pupuk organik dengan cara meletakkan kotoran sapi segar ditanah dan ditunggu beberapa minggu hingga berubah menjadi pupuk organik.pupuk ini digunakan untuk memupuk tanaman sendiri atau dijual ke pihak lain. Hal ini mengganggu kebersihan lingkungan karena kotoran sapi menimbulkan bau yang kurang sedap dan efek rumah kaca yang dihasilkan oleh gas metan. Dalam kegiatan pengabdian masyarakat IbM, masyarakat mitra diajak tim pengabdi untuk bersama-sama membangun instalasi biogas untuk dimanfaatkan sebagai sumber api kompor dan pupuk cair . pupuk cair ini digunakan sebagai pupuk tanaman pertanian wisata organik milik warga mitra di desa Hadiwarno Kata kunci : desa Hadiwarno, biogas, Pacitan, sapi, kotoran sapi
\end{abstract}

\section{LATAR BELAKANG}

Desa Hadiwarno, Kecamatan Ngadirojo, Kabupaten Pacitan, adalah sebuah desa yang berada didekat pantai lautan Indonesia dan merupakan wilayah Jawa Timur bagian barat yang berbatasan langsung dengan provinsi Jawa Tengah. Salah satu bentuk usaha perekonomian yang dijalankan oleh warga Kab. Pacitan adalah beternak sapi yang dilakukan secara berkelompok. Kelompok tani mitra adalah kelompok peternak sapi potong beranggotakan 43 orang dan masing-masing petani memiliki 2-3 ekor sapi yang dikelompokkan dan ditaruh dalam satu kandang bersifat komunal (milik bersama). Satu kandang berisi 8-12 ekor sapi.

Ketua 2 kelompok mitra yaitu :

Mitra 1 P. Tumidjo (desa Hadiwarno RT03/RW2) beranggota 21 orang. Mitra 2 P. Barwan (desa Hadiwarno RT05/RW1) ber anggota 22 orang. 
Produksi yang dihasilkan adalah : sapi, pupuk organik dari limbah sapi dengan kapasitas produksi perhari 1,72 ton / hari (basah) yang dijual ke pemilik tanaman yang membutuhkan pupuk kandang.

Aspek manajemen dalam pengelolaan ternak sapi diringkas sebagai berikut :

1. Sapi dibeli dengan biaya ditanggung anggota sendiri-sendiri.

2. Sapi masing-masing anggota dikandangkan bersama dalam kelompok besar untuk menjamin pengelolaan dan perawatan agar seragam dan efisien.

3. Penjualan sapi dilakukan sendiri oleh masing-masing peternak.

4. Pengelolaan dan penjualan limbah kotoran ternak sapi sebagai pupuk organik dilakukan secara berkelompok.

5. Pupuk organik sebagian dimanfaatkan untuk memupuk tanaman pakan sapi seperti skema di bawah ini.

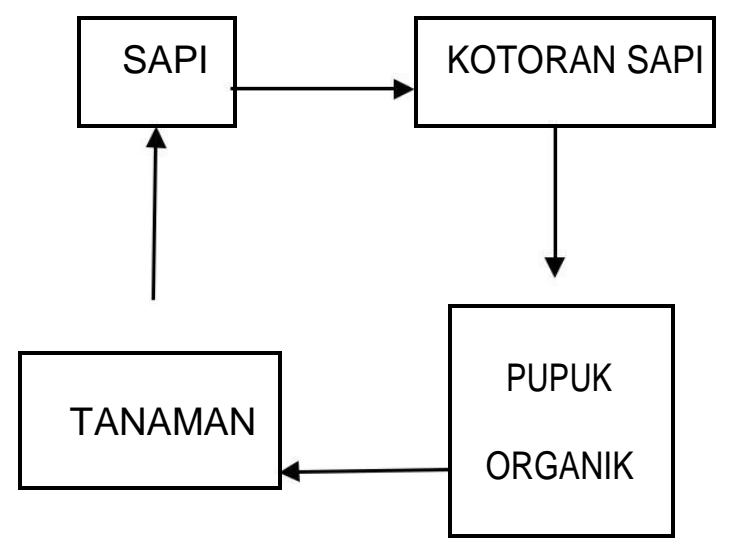

\section{PERMASALAHAN MITRA}

Secara umnum persoalan mitra adalah sebagai berikut :

(1) Kotoran sapi menimbulkan bau tak sedap saat dijadikan pupuk organik

(2) Belum mengenal pengelolaan instalasi biogas

(3) Belum bisa membuat pupuk cair

Solusi yang ditawarkan :

(1) Dibangun instalasi biogas

(2) Pelatihan pemanfaatan biogas

(3) Pelatihan pembuatan dan pengemasan pupuk cair 


\section{TARGET DAN LUARAN}

Target dan luaran hasil kegiatan secara ringkas adalah sebagai berikut :

\begin{tabular}{clll} 
No & \multicolumn{1}{c}{ Kegiatan } & \multicolumn{1}{c}{ Target } & \multicolumn{1}{c}{ Luaran } \\
1 & Membangun instalasi biogas & UKM petemak sapi & Alat (instalasi biogas) \\
2 & Pelatihan pupuk cair & UKM petemak sapi & $\begin{array}{l}\text { Metode (pembuatan } \\
\text { pupuk cair) }\end{array}$ \\
3 & Pelatihan operasi biogas & UKM petemak sapi & $\begin{array}{l}\text { Metode (operasi } \\
\text { biogas) }\end{array}$
\end{tabular}

\section{METODE PELAKSANAAN}

Metode yang dilaksanakan dalam pelaksanaan pengabdian adalah sebagai berikut :

- Sosialisasi kegiatan ke mitra UKM,

- pembangunan instalasi biogas dan pelatihan biogas

- pengujian instalasi biogas dilanjutkan dengan pendampingan pemakaian instalasi biogas ke mitra

- pemberian pelatihan perawatan dan pengoperasiannya ke UKM Mitra.

- Pelatihan pembuatan pupuk cair.

- Evaluasi kegiatan yang dilakukan antara tim pengabdi PT bersama Mitra UKM.

Dalam kegiatan ini mitra pe ternak diminta partisipasinya dalam bentuk :

1. Memberi bantuan tenaga kerja sebagai pembantu dalam pelaksanaan berbagai kegiatan yang dilangsungkan.

2. Mitra memberi bantuan dalam bentuk peralatan kerja atau sejenisnya dalam melengkapi penyempurnaan hasil kegiatan.

3. Menyediakan tempat tinggal untuk tim pengabdi karena kegiatan akan berlangsung cukup lama dan tempat tinggal pengabdi jauh dari lokasi kegiatan.

\section{HASIL YANG DICAPAI}

Kegiatan yang telah dilakukan berakhirnya kegiatan IbM berupa :

1. Meng koordinasikan pelaksanaan kegiatan dengan mitra peternak sapi

2. pembuatan instalasi biogas bersama-sama masyarakat.

3. Menguji dan mendampingi masyarakat dalam menggunakan biogas sebagai sumber energi alternatif

4. Pelatihan pemanfaatan pupuk organik cair dari sisa biogas. 


\section{KESIMPULAN DAN SARAN}

Kesimpulan :

1. Masyarakat sangat membantu dalam pelaksanaan kegiatan dalam bentuk tenaga kerja, tempat tinggal, akomodasi, transportasi dan informasi

2. Kegiatan perlu dikembangkan dalam hal sistem pertanian terpadu di lokasi wisata pantai desa Hadiwarno untuk mendukung kemandirian masyarakat dalam bidang ekonomi.

\section{DAFTAR PUSTAKA}

http://id.wikipedia.org/wiki/Ngadirojo, Pacitan diakses 22 April 2013, malang

Wahyuni, Sri. 2008. Biogas.Penebar Swadaya: Depok

www.pacitankab.go.id.diakses 9 april 2013 : Malang

www.suaradesa.com diakses diakses 22 April 2013, malang 